\title{
The interaction of spatial planning and transport policy: A regional perspective on sprawl
}

\author{
Veronika Kulmer ${ }^{a}$ \\ University of Graz \\ averonika.kulmer@joanneum.at \\ Bernhard Fürst \\ Verkehrsplanung Käfer $\mathrm{GmbH}$
}

\author{
Olivia Koland \\ University of Graz
}

\author{
Andreas Käfer \\ Verkehrsplanung Käfer GmbH
}

\author{
Karl W. Steininger \\ University of Graz
}

\begin{abstract}
Urban sprawl is caused by the interlinkage of spatial planning and transport characteristics. However, there are only a few approaches that quantify the cross-impacts of policy options in these two spheres. The purpose of this paper is thus a combined regional analysis of spatial planning instruments and transport policy, with a special emphasis on urban-rural diversities. We link a multi-region computable general equilibrium model that incorporates elements of the new economic geography with a transport forecast model. The general equilibrium model illustrates residential choice between urban and peripheral regions, while the transport model depicts the transport implications thereof. Our results suggest that transport policy is obviously effective in addressing transport externalities, while it would have to be set at a politically infeasible stringency to have an effect on residential patterns. As for spatial planning instruments (i.e., expanding housing supply in central regions or limiting it in peripheral regions), we find a strong potential to influence residential choice and hence urban sprawl. Along this line, spatial planning instruments do have a small but still significant impact on reducing transport volume and number of trips. This impact can be enhanced by a policy promoting public transport.
\end{abstract}

\section{Introduction}

Many urban areas in Europe are facing a spreading of residential land termed urban sprawl. Such residential development is driven by a complex set of factors, including population and economic growth, developments in housing/property markets, the lack of green and open space in cities, the available set of transportation possibilities, and the regulatory framework (e.g., land-use planning) (EEA 2006). In particular, low housing prices in suburban areas (compared to those in central sites) reduce the costs of living in non-central sites and make them attractive for settlement (Persky and Kurban 2003; Song and Zenou 2009). Another challenge Europe faces, reinforcing the spread between home and work/leisure locations, is urban-rural diversities.

While rural areas serve well as residential neighborhoods, they lack local suppliers, schools, and job opportunities, and urban and peri-urban areas are usually characterized by higher wages and stronger economic development (EU 2008; Batty 2002).

One key challenge arising with urban sprawl is elevated transport demand. Scattered residential patterns increase travel distances that link various locations (residences, work, shopping) (Rodrigue et al. 2006; Vance and Hedel 2007), especially connections from the periphery to the urban core (in partic- ular commuting connections) (Bontje, 2007; Travisiet al. 2010). In addition, urban sprawl has an indirect impact on mode choice in so far as scattered land use raises car dependency when public transport infrastructure is not sufficiently installed (Gallez and Orfeuil 1998; Glaeser and Kahn 2004). At the same time, urban sprawl raises the demand for infrastructure needed for road networks and water systems to link fragmented pieces of land (Najafi et al. 2007). As a consequence, urban sprawl raises concerns not only about environmental impacts (transport emissions and recirculation of pollutants), but also about land cover changes (increasing builtup areas and infrastructure). Considering these developments, urban sprawl ranks high on European policy agendas, challenging urban developers and policy makers.

From an economic theory point of view, the main reason for excessive urban sprawl is persisting market failures in both the transport sector and the housing market. Regarding the transport sector, external effects such as health, climate change, and environmental impacts remain to a large extent unaccounted for in transport prices, particularly so in road transport (Verhoef 1994). With respect to the housing market, urban sprawl reflects inefficient land use. In low-density, peripheral areas, the housing market may be governed by incorrect pricing of development services. Costs of living farther out are kept artificially low, when extensions of road infra- 
structure or the water system are financed by metropolitan-wide taxes. Then, developers or buyers of newly developed peripheral property do not fully internalize the cost of locating farther out. This promotes scattered housing development and large areas per housing unit (see Speir and Stephenson 2002; Najafi et al. 2007, Radeloff et al. 2005).

As these two markets (transport and housing) interact, so do their externalities (for empirical studies see Grazi et al. 2008; Ewing et al. 2003; Trowbridge and McDonald 2008). The total cost of locating farther from city centers involves both transport externalities and additional costs of development services. Thus, both costs should be passed on to developers or potential buyers and internalized by them so as to develop the land more densely.

Although urban sprawl is obviously interacting with distortions in both transport and land markets, policy makers often still devise separate and isolated instruments to combat sprawl. Up to now, to dampen increased transport demand, standard transport pricing instruments have been complemented by command and control instruments such as parking management or access restrictions for car drivers. Still, the remaining external costs of transport are large, and one reason may be found in scattered living (Meyers et al. 1996; Proost and van Dender 2011). As one alternative policy to address transport emissions, spatial planning has repeatedly been pointed out in mainly theoretical literature to influence both transport volume (via distances traveled) and mode choice. Thus, spatial measures such as enhancing mixed-use or high-density development may not only impact the housing market, but also reduce external costs of transport. To address this issue, the present study focuses on the interactions of policy measures to combat sprawl and aims to quantify the cross-impacts of measures.

To achieve this, transport demand and the location choice of agents between urban and rural regions are linked by combining a multi-region computable general equilibrium (CGE) model (residential choice model, RCM) with a transport forecast model (TFM), that is explicit about route choice, mode choice, and the transport network (for classical transport models see Lohse 1997; Kutter 2003). The issues of linking transport and land-use spheres have been intensively addressed by integrated landuse and transport models (Waddell 2002; Anas and Liu 2007; Abraham and Hunt 2002; see Wegener 2005 for an overview). Our modeling approach, however, contributes to existing developments in several dimensions. First, from a content-based point of view, we consider economic diversities between rural and urban areas as an additional aspect in residential location choice, while most integrated transport and land-use models address location and transport choice within metropolitan areas (see Wadell 2000; Anas 1998). These regional differences concern income, housing prices, transport costs, and local supply in goods and services. To study relative regional differences, we differentiate between various types of representative regions in the economic model while abstracting from a finer level of resolution (such as a spatial grid or city quarter). Second, in contrast to previous attempts ranging from Lowry (1964) and MUSSA (Martinez 1992, 1997) to MEPLAN (Echenique et al. 1969; Hunt 1993), our approach builds on economic theory to address a joint choice of job location and residence. In particular, we use elements of the new economic geography (NEG) as modeling guidance (for overviews see Fujita et al. 1999 and Baldwin et al. 2003). This allows us to acknowledge households' taste for variety (accomplished by the implementation of Dixit-Stiglitz representations of production and utility functions). Third, the equilibrium framework we use enables the consideration of various economic markets simultaneously, such as local housing, labor, and product markets, which are crucial for location decisions. The equilibrium approach ensures that wages and housing prices are market clearing, a fact not covered by utilitymaximizing multinomial logit-based models such as Urbansim (Waddell 2000, 2002). Fourth, the linkage of RCM and TFM makes land use endogenous in transport forecasting. Therefore, travel demand estimated in TFM responds to RCM output on landuse changes and thus extends previous transportrelated studies treating land use as exogenous (for an overview see Boyce and Bar-Gera 2003).

With this model framework we are thus in the position to analyze, on the one hand, the direct link of spatial planning instruments on land use and housing prices and its indirect potential to contribute to transport prevention. On the other hand, we analyze the direct impact of transport pricing policies on transport demand (as is most often covered) and also the potential of transport policy to influence residential choice (as an indirect link).

As for the structure of this paper, Section 2 lays out the methodological approach and model linking. 
The modeling device is then implemented to a regional setting (see Section 3 for the study region and calibration process). Sections 4 and 5 describe the results of analyzing separate and combined spatial planning and transport pricing policies. Section 6 discusses the results, and Section 7 concludes.

\section{Methodological approach}

In order to quantify the effects of different spatial and transport policy instruments on residential spatial structure, transport demand, number of trips, and modal split, we link an economic spatial general equilibrium model of residential choice (RCM) with a standard transport forecast model (TFM).

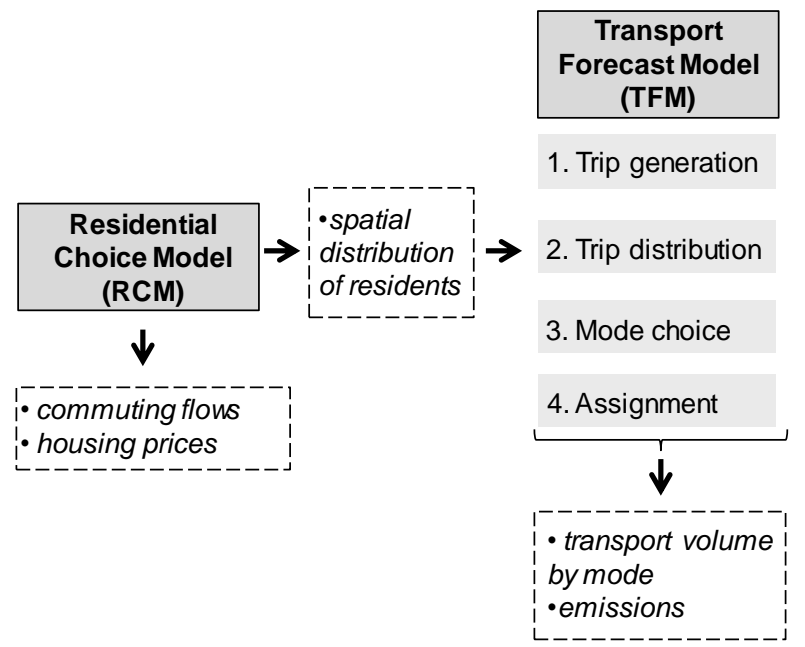

Figure 1. Model interface

For policy simulation, we adopt a sequential model linking of RCM and TFM (see Figure 1). First, different policy scenarios are implemented in RCM to gain impacts on spatial distribution of workforce residence and job location, commuting flows, and housing prices. Then, the resulting changes in the spatial distribution of residential population are input in TFM to determine trip distribution. Finally, TFM reports on changes in transport volume, number of trips, modal split, and transportrelated emissions (for details regarding the model interface, see an illustrative example in the Appendix).
2.1

\section{The residential choice model}

The residential choice model is a multi-region static CGE model that explains households' choice of residence and place of work. In this framework, residential location choice is defined on a regional scope between representative region types characterizing urban and rural diversities (e.g., housing prices, wages, transport costs, product variety). RCM uses the NEG literature as guidance (see, e.g., Fujita et al. 1999). It is based on the stylized model of Bednar-Friedl et al. (2011), which extends the coreperiphery model of Krugman (1991a, b) by incorporating competitive housing market interactions, commuting flows, and local environmental aspects. We go beyond Bednar-Friedl et al. (2011) and expand the bi-regional structure to a multiregional structure $(\mathrm{s}, \mathrm{r}=1, \ldots, \mathrm{R})$, while we abstract from environmental quality modeling. In doing so, the CGE model allows addressing urban-rural issues in more spatial and economic detail. To capture differences in urban and rural locations and the dynamics of resettlement, we distinguish four region types, each with representative character (see Section 3).

In this setting, utility-maximizing consumers are mobile between the regions and decide where to live and where to work. ${ }^{1}$ The migration decision of consumers depends on regional differences in housing prices, transport costs, and product variety. In the economy, two commodities are produced, namely a housing good $(H)$, subsuming all housing expenditures (e.g., shelter and utilities, operations and supplies), and a macro good $(M)$, which is an aggregate of all other consumption goods (in terms of product varieties). Both commodities are tradable between and within the regions. Trade of the aggregated macro good represents shopping traffic, while trade of the housing good represents commuting.

In terms of residential choice, workers can migrate to other regions, but housing production in each region is fixed in quantity $\bar{H}_{r}$ (with endogenous prices). Oversupply and undersupply across the regions may occur, and the arising housing prices may induce a proportion of the population to com-

\footnotetext{
${ }^{1}$ Note that regions are modeled as economic regions and that in economic terms the population of a specific region corresponds to the regional workforce. Part of that workforce may live in that specific region (and thus also be residents of that region); the other part of it may live elsewhere and commute.
} 
mute to another region (i.e., the housing good is "exported" to the other region). Housing demand for commuters $H_{s r}$ (job location in $s$ and residence location in $r$, with $s \neq r$ ) can be written as

$H_{s r}=b_{r, 0} * \overline{H_{r}} *\left(\frac{\sum_{s=1}^{R} b_{s r, 0}\left(\frac{P^{H} r}{T^{H} s r}\right)^{\omega}}{\frac{P^{H}}{T^{H}}}\right)^{\varepsilon}$

With

$b_{r, 0} \quad$ reference level of housing exports of region $r$,

$b_{s r, 0}$ share of labor employed in region $s$ that commutes from region $r$,

$H_{r} \quad$ fixed housing supply in region $r$,

$P^{H}{ }_{r(s)}$ price of housing in region $r(s)$,

$T^{H}{ }_{s r}$ interregional transport costs,

$T_{\text {ss }}^{H}$ intraregional transport costs,

$\omega$ elasticity of substitution within housing abroad,

$\varepsilon \quad$ elasticity of substitution between housing in the home region and housing abroad.

Thus, the decision to either commute or to migrate to the region of job location depends on the relative regional housing price and on relative transport costs (see also Figure A-2 in the Appendix). In terms of the latter, we distinguish interregional $\left(T^{H}{ }_{s r}\right)$ and intraregional transport costs $\left(T^{H}{ }_{s s}\right)$, with $T^{H}{ }_{s r}>T^{H}{ }_{s s}$. Moreover, in our setting, transport costs represent road distance between regions or within a region. ${ }^{2}$ Transport costs rise linearly with road distance. In correspondence with the robust empirical observation that, in terms of transport aspects, it is commuting trips that are most relevant for residential location choice $^{3}$, in our set-

${ }^{2}$ Road distance is measured either (i) as average distance between all possible combinations of origin and destination in the same region (intraregional transport costs) or (ii) as average distance between all possible combinations of origin and destination in different regions (interregional transport costs).

${ }^{3}$ For example, Belart (2011) finds that-after closeness to friends (which cannot be economically depicted) - it is the mean distance to work that dominates all other spatial factors in residential home location choice. ting it is also commuting trips (and their costs) that enter the residential choice decision. Furthermore, it is empirically evident that, in a regional setting, location choice is mainly driven by significant differences in housing prices, wages, and transport costs (Kim et al. 2001; Henry and Barkley 1997). In our analysis, focusing on diversification across region types, we abstract from particular housing attributes (such as type of dwelling, number of rooms, year of construction) as well as household characteristics (e.g., age, education level, number of children).

Finally, in the equilibrium, the housing supply must equal housing demand in each region:

$\overline{H_{r}}=H_{r r}+\sum_{s=1}^{R} H_{s r \mid s \neq r}$,

with

$H_{r r} \quad$ domestic housing demand,

$H_{s r \mid s \neq r \quad \text { housing exports from } \mathrm{r} \text { to } \mathrm{s} .}$

The housing supply of region $r$ is either demanded domestically (i.e., residence and job located in region $r$ ) or exported to the region of job location $s$, representing commuting from $r$ to $s$ (see also Equation 1).

All households are final consumers and share identical preferences for $H$ and $M$. The CobbDouglas $^{4}$ utility function of households working in region $r$ can be written as

$U_{r}(M, H)=M_{r}^{\alpha} * H_{r}^{1-\alpha}$,

With

$\alpha(1-\alpha) \quad$ expenditure share of $M(H)$,

$U_{r} \quad$ utility of households working in region $r$.

Then the utility of households working in region $r$ comprises households living either in regions $s$ (sum of housing imports from region $s$, $\sum_{s=1}^{R} H_{r s \mid s \neq r}$ ) or in region $r$ (not commuting between regions, $H_{r r}$ ). In terms of the macro good $M$,

${ }^{4}$ This implies that the elasticity of substitution, $\sigma$, between $\mathrm{M}$ and $\mathrm{H}$ is equal to 1 . 
we assume that households love variety and purchase differentiated goods produced in all regions (following Dixit and Stiglitz 1977). In the equilibrium, utility per household is equalized across regions such that no household has an incentive to relocate.

\subsection{The transport forecast model}

The transport forecast model (TFM) quantifies current and future transport demands and transport volume by mode based on economic (e.g., regional gross product and activity level by each economic sector) and socio-demographic factors (e.g., population, age of inhabitants, share of pupils and students). The TFM consists of two core models: a transportation network model and a passenger transport demand model.

The transportation network model contains a detailed representation of the road and rail networks as well as public transportation services (including timetables of bus and rail connections). Using this information, the study region is divided into traffic zones representing trip origins and destinations. Each zone $i$ (with alias $j$ ) is connected to the transportation network by links between the centroid of the zone and the assigned access points (nodes of the road network and public transport stops). A link is defined by the distance between origin and destination as well as by specific criteria such as type of road, capacity, or speed limits. These criteria result in travel time and level of service offered between two nodes. The passenger transport demand model follows the traditional four-step approach (Kutter 2003):

1. Trip generation: The first step determines total transport demand (number of trips by trip purpose) originating from each zone $(i)$ as a function of population and demographic and socioeconomic variables (e.g., age, employment, passenger car availability) as well as the transport behavior of well-defined user groups $(g)$ of the transport system. User groups are defined by age as well as by the daily number and purpose of trips.

2. Trip distribution: The number of trips determined in step 1 is allocated to destination zones by using a gravity model function. The gravity function is based on the spatial distribution of the population and the related points of destina- tion (attractions) such as job locations, shopping facilities, schools, and leisure facilities. Equation 4 shows the gravity function for each user group $(g)$ and trip purpose $(z)$ :

$$
F_{i j}=\frac{Q_{i} Z_{j} L_{j} f\left(W_{i j}\right)}{\sum\left(z_{j} L_{j} f\left(W_{i j}\right)\right)},
$$

with

Fij trips from zone i to zone $j$,

$Q i \quad$ trips originating in zone $i$,

$Z j \quad$ relative attractiveness of zone $j$ (based on number of attractions in zone $j$ compared to all other zones),

$L j \quad$ relative accessibility of zone $j$ (compared to all other zones),

Wij resistance between zone $i$ and zone $j$ (e.g., congestion level).

A capacity-constraint function limits the transport demand according to distance and attraction of points of destination as follows:

$f\left(W_{i j}\right)=e^{-\beta W_{i j}} W_{i j}^{\gamma}$,

with $\beta$ and $\gamma$ representing resistance parameters for each user group $g$ and trip purpose.

The parameters $Q i$ and $Z j$ are determined by the spatial distribution of residential population in RCM. Due to the higher spatial resolution in TFM, the following steps are necessary:

- Assignment of each traffic zone, $i$ (implemented as a separate unit in TFM), to one representative region, $r$, in $\mathrm{RCM}$

- Extrapolation from workforce population (as modeled in RCM) to entire population (as modeled in TFM), considering different household sizes per region

- Splitting the population into user groups $(g)$ with homogenous travel behavior

3. Mode choice: At this stage, the generated trips between each origin and destination zone are allocated to the different modes of transport (motorized individual transport, public transport, bike and pedestrian). In order to derive the relative share of each mode, we use a Box-Cox model with the general form: 
$P_{i j}(m, g, z)=\frac{e^{\beta b\left(T, V_{i j}(m, g, z)\right.}}{\sum e^{\beta b\left(T, V_{i j}(m, g, z)\right.}}$

where

$b\left(T, V_{i j}(m, g, z)=\frac{\frac{V(m, g, z)^{T}-1}{T} \text { for } T \neq 0}{\ln \left(V_{i j}(m, g, z)\right) \text { for } T=0}\right.$

Then, the utility of mode $m$ for group $g$, trip purpose $z$, and relation $i$ to $j, \operatorname{Vij}(m, g, z)$ is determined considering all components of a trip from origin to destination (e.g., travel time, quality of the transportation network, public transport services offered). In the Appendix, the utility functions for two modes are illustrated: motorized individual transport and public transport.

4. Assignment: Finally, trips given for a particular mode of transport are assigned to concrete routes in the transportation network, thereby considering capacity constraints (potentially resulting in detour transport and/or change of travel destination due to congestion).

\section{Regional application}

\subsection{The case study region}

The study region comprises the commuter catchment area of an urban core. As an urban core, we choose the city of Graz, the second largest city in Austria with an area of $128 \mathrm{~km}^{2}$ and a population of 240,000 inhabitants. To delimit the commuter catchment area, we consider all municipalities that lie within a maximum vehicle trip time of 60 minutes. This results in 350 municipalities, which differ in terms of residential density, local supply of varieties, outward commuter share, and public transport supply (number of stops and travel time to the central urban region). Municipalities are aggregated to regions, initially intended to limit the degree of complexity in $\mathrm{RCM}^{5}$, but also serving to account for the limited data availability at the munici-

5 The challenge in obtaining solutions in the present NEG-based model (RCM) (i.e., determining a spatial equilibrium over the regions) is the differentiation along two dimensions: one being the differentiation of varieties of goods produced in the monopolistically competitive market and the other being the spatial differentiation. pal level ${ }^{6}$ (local administrative unit, LAU), such as with respect to housing prices. Four types of regions are defined - central urban (CU), peri-urban (PU), densely populated rural (DR), and sprawled rural (SR) - following the OECD (2010) typology of urban and rural areas and the remoteness index of Australia (ARIA) (DHAC 2001) (for details, see Table A-1 in the Appendix).

Table 1 gives the main characteristics of the four representative region types in terms of aggregated and average values for municipalities assigned to each type. The majority of municipalities are classified as rural, in either DR or SR regions. CU and PU regions have by far the highest number of workers. However, their residential population is comparatively low. CU regions represent employment and industry centers with a high share of shopping and recreation possibilities, but they are not favored residential areas. One reason for this is that land prices are extremely high (ten times that of SR and DR regions). By contrast, SR regions have the highest share of residential population, but they do not offer sufficient workplaces for their residents. SR and DR regions could be called "bedroom communities" because they lack the full range of local suppliers, services, workplaces, and infrastructure. As a consequence, DR and SR regions show- with an average of more than 70 percent - the highest outwardcommuting share.

${ }^{6}$ In terms of economic data, municipalities are the finest level of spatial resolution (data at the zone level is available for distinct urban areas but not comprehensively for a whole region or province). In Austria, data is collected as part of the national census. Yet, the number of economic variables available at the municipal level is limited. 
Table 1: Characterization of representative region types

\begin{tabular}{lrrrr}
\hline & $\begin{array}{r}\text { Central } \\
\text { urban } \\
\text { (CU) }\end{array}$ & $\begin{array}{r}\text { Peri- } \\
\text { urban } \\
\text { (PU) }\end{array}$ & $\begin{array}{r}\text { Densely } \\
\text { populated } \\
\text { rural (DR) }\end{array}$ & $\begin{array}{r}\text { Sprawled } \\
\text { rural (SR) }\end{array}$ \\
\hline $\begin{array}{l}\text { Number of } \\
\text { municipali- } \\
\text { ties (TAZs) }\end{array}$ & & & & \\
$\begin{array}{l}\text { Residential } \\
\text { density (per- }\end{array}$ & 1 & 15 & 94 & 241 \\
$\begin{array}{l}\text { sons per km }{ }^{2} \\
\text { residential }\end{array}$ & & & & \\
area) & 2495 & 1135 & 402 & 311 \\
$\begin{array}{l}\text { Residents } \\
\begin{array}{l}\text { Workforce } \\
\text { Average }\end{array}\end{array}$ & 239,500 & 153,218 & 182,426 & 316,240 \\
outward & 158,268 & 100,999 & 58,834 & 63,505 \\
commuter & & & & \\
share [\%] & 17 & 48 & & \\
\hline
\end{tabular}

Source: Statistics Austria (2002, 2003, 2004)

\subsection{Calibration to the initial database}

RCM is calibrated to the spatial distribution of the residential population and workforce across the regions in 2001. We use commuter data and housing prices from national censuses (Statistics Austria $2003,2004,2005$ ) and parameter values as given in Table 2. For parameterization of transport costs, RCM uses generalized transport costs from TFM, measured by resistance between representative regions (i.e., regionally aggregated resistance parameter $W i j)$. Furthermore, the elasticities $\omega$ and $\varepsilon$ are calibrated as a set to reproduce the spreading of residential population and workforce across regions. In doing so, the following quantitative criteria with respect to the case study area have to be satisfied: (i) ranking between regions regarding the distribution of residential population and workforce (as reported in Table 1), (ii) relative distribution of housing prices over the regions, (iii) ranking between regions with respect to production and consumption possibilities, and (iv) less than 10 percent bias between calibrated and real distribution in each region (see Table A-2 in the Appendix).

${ }^{7}$ Basically, we use municipalities as traffic analysis zones (TAZs). Therefore, the number of TAZs within a region equals the number of municipalities as shown in the table above (except for the CU region, which is one municipality but split into three TAZs).
Table 2: Parameters for calibration of RCM

\begin{tabular}{|c|c|c|}
\hline Elasticity/parameter & & Source \\
\hline $\begin{array}{l}\text { Elasticity of substitution } \\
\text { between varieties (manu- } \\
\text { facturing goods from all } \\
\text { regions) }\end{array}$ & $v=5$ & $\begin{array}{l}\text { Eppink and } \\
\text { Withagen (2009) }\end{array}$ \\
\hline Expenditure share of $M(H)$ & $\begin{array}{l}\alpha \\
0.6 \\
(0.4)\end{array}$ & $\begin{array}{lr}\text { consumer } & \text { survey } \\
\text { (Statistics } & \text { Austria } \\
\text { 2006) } & \end{array}$ \\
\hline Iceberg transport costs & $\begin{array}{l}T_{H}, \\
T_{M}\end{array}$ & $\begin{array}{l}\text { Provided by TFM } \\
\text { as generalized } \\
\text { transport costs } \\
\text { (between and } \\
\text { within the four } \\
\text { types of region) }\end{array}$ \\
\hline $\begin{array}{l}\text { Elasticity of substitution } \\
\text { within housing demand } \\
\text { abroad; among regions that } \\
\text { households are commuting } \\
\text { from } \\
\text { Elasticity of substitution } \\
\text { between domestic housing } \\
\text { and housing abroad }\end{array}$ & $\omega=0$ & $\begin{array}{l}\omega \text { and } \varepsilon \text { are cali- } \\
\text { brated as a set to } \\
\text { reproduce the } \\
\text { spatial distribu- } \\
\text { tion of the resi- } \\
\text { dential population } \\
\text { and workforce } \\
\text { across regions }\end{array}$ \\
\hline
\end{tabular}

TFM is calibrated to the base year 2005 and was developed as part of the Austrian traffic forecast 2025+ (for details, see Käfer et al. 2009). TFM reproduces a sound approximation of observed data on traffic volume and traffic network load of passenger and freight transport in Austria.

\subsection{Business-as-usual scenario}

To account for the long-term nature of spatial planning instruments, the policy analysis is carried out for the year 2025. We use the projection of demographic, economic, and infrastructural trends of the TFM based on the Austrian transport forecast $2025+$. Table 3 shows the spatial distribution of residential population, transport volume, and number of trips for the business-as-usual scenario (BaU 2025). 
Table 3: Definition of BaU 2025 (no-policy case)

\begin{tabular}{llllllr}
\hline \multicolumn{1}{c}{} & CU & PU & DR & SR & \multicolumn{1}{c}{ Total } \\
\hline \multirow{2}{*}{ Residential population } & $27.15 \%$ & $15.33 \%$ & $20.59 \%$ & $36.92 \%$ & 405,827 \\
& & & & & & \\
Transport vol- & MPT $^{\text {b }}$ & $23.26 \%$ & $14.01 \%$ & $22.08 \%$ & $40.64 \%$ & 20,802 \\
ume [p-km $]$ & PT $^{\text {c }}$ & $34.36 \%$ & $18.62 \%$ & $21.73 \%$ & $25.29 \%$ & 3309 \\
Number of trips & MPT & $29.25 \%$ & $18.30 \%$ & $20.08 \%$ & $32.37 \%$ & $1,855,130$ \\
& PT & $43.49 \%$ & $20.92 \%$ & $16.65 \%$ & $18.94 \%$ & 442,500 \\
\hline a) p-km: kilometer per person.
\end{tabular}

Source: Käfer et al. (2009)

The BaU 2025 scenario serves as reference case for policy simulation. First, we analyze the impacts of two spatial planning instruments on land use and transport. Furthermore, in terms of transport effects, we model an improved access to public transport as a supplement to both spatial planning instruments. Finally, we investigate land-use changes and impacts on transport demand of a transport pricing policy.

\section{Policy simulation of spatial planning measures}

Spatial planning instruments regulate the availability of housing and ensure that site development is welldimensioned relative to the transport network, the size of the labor force, and the local residential population. In our simulations, we distinguish two types of planning measures:

- housing area limitations in rural regions, both in sprawled rural (SR) and densely populated rural (DR) areas, and

- expansion of housing availability or building land in urban (CU) and peri-urban (PU) areas.

Area-limiting instruments such as strong landuse planning via supra-local plans regulate arbitrary zoning at the municipal level. They primarily aim to minimize the dedication of new building land in non-central sites. By contrast, instruments that expand housing availability in central regions, such as strict enforcement of existing zoning plans, aim to mobilize existing building land and thereby promote the re-use of vacant land.

To allow a comparison of measures, both instruments are implemented at a stringency level that reduces outward commuters originating in peripheral regions (DR and SR) to any other region (except their own) by 10 percent. The arising scales of the expansion of building land in central regions (41 percent) as well as that of area limitation in rural regions (34 percent) by setting these measures are levels currently well discussed within policy arenas.

We analyze spatial planning instruments with respect to (i) the direct impact on land use in terms of housing prices and residential population and (ii) the indirect impact on transport measured in transport volume, number of trips, and modal split. We define transport volume per region to include all traffic flows within the region or originating from it. In terms of modal split, we capture the following modes of transport: car driver, car passenger, public transport, bike, and pedestrian.

Finally, we investigate the effect of a combination of spatial planning and public transport policy measures to detect whether and how strong changes in land use can trigger transport volume and mode changes when not only transport demand is changed (by spatial planning), but also supply characteristics (enhancing public transport). We implement the additional measure in TFM by lowering the distances between residences (centroids of traffic zones) and public transport stops (access points to public transportation network) by 40 percent.

\subsection{Effects of spatial planning on land use (direct effects)}

Considering land-use changes for both planning measures investigated, we observe a high influx of residential population to $\mathrm{CU}$ and $\mathrm{PU}$ regions, whereas DR and SR regions experience a significant loss in residential population (see Table 4). The more densely populated DR region shows a substantially higher decrease in residential population compared to SR. The main reason for substantial impacts of spatial planning on residential development 
can be found in altered property (and thus housing) prices, which respond to the quantitative limitation/expansion in available housing supply. Prices are, for instance, doubled under area limitation in DR.

Table 4: Changes in residential population and housing prices for area limitation and expansion of building land compared to BaU 2025

\begin{tabular}{llllll}
\hline & $\begin{array}{c}\% \text { Changes } \\
\text { in }\end{array}$ & CU & PU & DR & SR \\
\hline Area limitation & & & & & \\
& $\begin{array}{l}\text { Residential } \\
\text { population }\end{array}$ & $+11.34 \%$ & $+12.65 \%$ & $-17.15 \%$ & $-5.13 \%$ \\
$\begin{array}{l}\text { Expansion of } \\
\text { building land }\end{array}$ & & $+8.36 \%$ & $+12.25 \%$ & $-16.43 \%$ & $-2.67 \%$ \\
Area limitation & Housing & $-18.00 \%$ & $-23.00 \%$ & $+101.00 \%$ & $+15.00 \%$ \\
$\begin{array}{l}\text { Expansion of price } \\
\text { building land }\end{array}$ & & $-33.00 \%$ & $-39.00 \%$ & $+49.00 \%$ & $+2.00 \%$ \\
\hline
\end{tabular}

Table 5: Changes in number of trips and transport volume of motorized private passenger transport of spatial planning instruments relative to $\mathrm{BaU} 2025$

\begin{tabular}{|c|c|c|c|c|c|c|}
\hline & $\begin{array}{c}\% \text { Changes } \\
\text { in }\end{array}$ & $\mathbf{C U}$ & PU & DR & SR & Total \\
\hline Area limitation & \multirow{2}{*}{$\begin{array}{l}\text { Transport } \\
\text { volume }\end{array}$} & $-0.92 \%$ & $+0.84 \%$ & $-7.98 \%$ & $-3.32 \%$ & $-3.21 \%$ \\
\hline $\begin{array}{l}\text { Expansion of } \\
\text { building land }\end{array}$ & & $-0.62 \%$ & $+1.08 \%$ & $-7.39 \%$ & $-1.79 \%$ & $-2.35 \%$ \\
\hline Area limitation & \multirow{2}{*}{$\begin{array}{l}\text { Number of } \\
\text { trips }\end{array}$} & $+3.88 \%$ & $+4.14 \%$ & $-7.91 \%$ & $-2.84 \%$ & $-0.59 \%$ \\
\hline $\begin{array}{l}\text { Expansion of } \\
\text { building land }\end{array}$ & & $+2.99 \%$ & $+4.33 \%$ & $-7.25 \%$ & $-1.35 \%$ & $-0.22 \%$ \\
\hline Area limitation & \multirow{2}{*}{$\begin{array}{l}\text { Trips } \\
\text { capita }\end{array}$} & $-7.08 \%$ & $-7.93 \%$ & $+10.70 \%$ & $+2.00 \%$ & $-0.62 \%$ \\
\hline $\begin{array}{l}\text { Expansion of } \\
\text { building land }\end{array}$ & & $-5.17 \%$ & $-7.26 \%$ & $+10.74 \%$ & $+1.13 \%$ & $-0.23 \%$ \\
\hline
\end{tabular}

Table 6: Changes in modal split of spatial planning instruments relative to BaU 2025

\begin{tabular}{llllll}
\hline & Car & Public transport & Car passenger & Pedestrian & Bike \\
\hline $\begin{array}{l}\text { Area limitation } \\
\begin{array}{l}\text { Expansion } \\
\text { building land }\end{array}\end{array}$ & $+0.68 \%$ & $-5.74 \%$ & $-0.65 \%$ & $+11.90 \%$ & $+9.09 \%$ \\
\hline
\end{tabular}

\subsection{Effects of spatial planning on transport (indi- rect effects)}

In case of both spatial planning instruments, the loss in residential population in rural regions DR and SR (see Table 4) causes number of trips and transport volume to fall (see Table 5). By contrast, the rise in residential population in $\mathrm{CU}$ and $\mathrm{PU}$ leads to an increase in number of trips but, overall, to shorter dis- tances traveled. While trips rise in number, transport volume falls because the $\mathrm{CU}$ and PU regions are characterized by compact and mixed-use neighborhoods. Moreover, due to population influx in $\mathrm{CU}$ and PU, the number of trips per capita falls.

In terms of modal split (see Table 6), we find that both area limitation and expansion of building land considerably promote environmentally friendly passenger transport, in particular bike (up 9 percent) and pedestrian (up 12 percent). Measured in abso- 
lute value terms, however, the impact is negligible. The effects of spatial planning instruments on number of trips of car drivers and car passengers are of minor importance.

\subsubsection{Effects of spatial planning plus improved ac- cess to public transport on transport (indirect effects)}

To enhance the indirect impact of spatial planning instruments on modal split, we simulate improved access to public transport as a supplement to each of the two spatial planning instruments (area limitation and expansion of building land). More precisely, we lower the distances between residences (centroids of traffic zones) and public transport stops (access points to public transportation network) in TFM by 40 percent.

The combination of measures, as shown in Table 7 , causes a substantial fall in the number of trips of motorized private passenger transport in peripheral regions (DR and SR). It further slows down the rise in trips in PU and even reverses the former finding for CU. In addition, the impact on trips per capita is stronger. In terms of transport volume of motorized private passenger transport, we find a considerable reduction in all regions, being most effective in DR (see Table 7).

Table 7: Changes in number of trips and transport volume of motorized private passenger transport of combined policy instruments relative to $\mathrm{BaU} 2025$

\begin{tabular}{|c|c|c|c|c|c|c|}
\hline & $\begin{array}{c}\% \text { Changes } \\
\text { in }\end{array}$ & $\mathbf{C U}$ & PU & DR & SR & Total \\
\hline $\begin{array}{l}\text { Area limitation \& public } \\
\text { transport }\end{array}$ & & $-12.83 \%$ & $-1.59 \%$ & $-14.83 \%$ & $-13.58 \%$ & $-12.16 \%$ \\
\hline $\begin{array}{l}\text { Expansion of building land } \\
\text { \& public transport }\end{array}$ & $\begin{array}{l}\text { Transport } \\
\text { volume }\end{array}$ & $-14.71 \%$ & $-6.44 \%$ & $-19.96 \%$ & $-8.32 \%$ & $-12.12 \%$ \\
\hline $\begin{array}{l}\text { Area limitation \& public } \\
\text { transport }\end{array}$ & & $-3.56 \%$ & $+2.68 \%$ & $-11.44 \%$ & $-6.20 \%$ & $-4.85 \%$ \\
\hline $\begin{array}{l}\text { Expansion of building land } \\
\& \text { public transport }\end{array}$ & & $-4.58 \%$ & $+2.87 \%$ & $10.76 \%$ & $-4.69 \%$ & $4.47 \%$ \\
\hline Area limitation \& public & & $-13.74 \%$ & $-9.22 \%$ & $6.46 \%$ & $-1.53 \%$ & $-4.85 \%$ \\
\hline & $\begin{array}{l}\text { Trips per } \\
\text { capita }\end{array}$ & & & & & \\
\hline $\begin{array}{l}\text { Expansion of building land } \\
\& \text { public transport }\end{array}$ & & $-12.14 \%$ & $-8.56 \%$ & $6.55 \%$ & $-2.29 \%$ & $-4.49 \%$ \\
\hline
\end{tabular}

Table 8: Changes in modal split of spatial planning instruments plus improved access to public transport relative to BaU 2025

\begin{tabular}{llllll}
\hline & Car & Public transport & Car passenger & Pedestrian & Bike \\
\hline $\begin{array}{l}\text { Area limitation \& public } \\
\text { transport }\end{array}$ & $-3.54 \%$ & $+16.24 \%$ & $+2.93 \%$ & $+23.21 \%$ & $+21.21 \%$ \\
$\begin{array}{l}\text { Expansion of building land } \\
\text { \& public transport }\end{array}$ & $-3.79 \%$ & $+22.89 \%$ & $-2.82 \%$ & $+18.45 \%$ & $+18.18 \%$ \\
\hline
\end{tabular}


As reported in Table 8, combining spatial planning with the promotion of public transport has a considerable impact on modal split with a substantial shift to environmentally friendly transport modesobviously public transport but also bike and pedestrian (for comparison see Table 6).

\section{Policy simulation of transport instru- ments}

Within transport policy, strategies and instruments to reduce commuting are manifold, such as demand side management, fiscal and regulatory policy, and technological improvements. This paper focuses on pricing instruments that affect variable car transport costs such as road pricing, cordon pricing, or fuel taxation. In particular, we investigate a 30 percent increase in variable car transport costs. Thereby, the residential population in regions DR and SR is affected more than in CU and PU by this measure (at equal kilometer rates), because variable transport costs are higher in terms of overall expenditure share (Statistics Austria 2006). The cost increase is simulated in both models (RCM and TFM), and the level of 30 percent might be considered at the upper bound of currently politically feasible levels.

We analyze transport policy regarding (i) the direct impact on transport demand and (ii) the indirect impact on land use and housing prices.

\subsection{Effects of transport policy on land use (indi- rect effects)}

Results in Table 9 report that increased variable car transport costs hardly affect residential structures. We only find a small fall in residential population in SR (below 1 percent) and a negligible increase in population in the three other regions (with a range between 0.15 percent and 0.60 percent). The effect on the level of housing prices by the transport policy reflects this results which stays below a 1.5 percent shift. We conclude that transport costs play a minor role in households' residential choice and thus have only a negligible impact on land use and land-use change.
Table 9: Changes in residential population and housing prices of increase in transport costs relative to $\mathrm{BaU} 2025$

\begin{tabular}{lllll}
\hline & CU & PU & DR & SR \\
\hline $\begin{array}{l}\text { Residential } \\
\text { population }\end{array}$ & $+0.22 \%$ & $+0.19 \%$ & $+0.56 \%$ & $-0.80 \%$ \\
Housing price & $+0.69 \%$ & $+1.46 \%$ & $+0.45 \%$ & $+1.50 \%$ \\
\hline
\end{tabular}

\subsection{Effects of transport policy on traffic (direct effects)}

As expected, results on transport flows are more pronounced. For instance, in contrast to spatial planning measures, the fall in transport volume is substantial (in total, 6.5 percent). Table 10 suggests that higher transport costs lead people to drive shorter distances rather than to take fewer trips. This result is also reflected by the small impact on trips per capita (total trips per capita only fall by 0.5 percent). Moreover, the 30 percent higher variable car transport costs imply a considerable reduction of transport volume of motorized private passenger transport in all areas. This concerns mainly shopping and leisure trips, as the spatial allocation of workplaces and places of residence are hardly affected (see 6.1). DR and SR are most affected and thus show the highest reduction. One main reason for that is again found in the higher share of variable transport costs in total consumption budgets in these regions relative to $\mathrm{CU}$ and $\mathrm{PU}$. By contrast, in $\mathrm{CU}$ and PU we find both shorter distances and a shift to public transport.

Table 10: Changes in number of trips and transport volume of increase in transport costs relative to $\mathrm{BaU} 2025$

\begin{tabular}{|c|c|c|c|c|c|}
\hline & $\mathbf{C U}$ & PU & DR & SR & Total \\
\hline $\begin{array}{l}\text { Transport } \\
\text { volume }\end{array}$ & $-5.18 \%$ & $-4.80 \%$ & $-6.32 \%$ & $-7.91 \%$ & $-6.49 \%$ \\
\hline $\begin{array}{l}\text { Number of } \\
\text { trips }\end{array}$ & $-1.85 \%$ & $+1.37 \%$ & $-0.16 \%$ & $-0.61 \%$ & $-0.50 \%$ \\
\hline $\begin{array}{ll}\text { Trips } & \text { per } \\
\text { capita } & \\
\end{array}$ & $-3.14 \%$ & $0.08 \%$ & $-2.60 \%$ & $2.37 \%$ & $-0.52 \%$ \\
\hline
\end{tabular}

Moreover, higher transport costs favor environmentally friendly modes of transport (not shown in Table 10). Cyclists and pedestrians show a considerable increase in transport volume (more than 10 percent). Furthermore, public transport becomes more attractive and increases by more than 8 percent in volume. 
6

\section{Discussion}

We investigate the potential of spatial planning instruments and transport policy to reduce both market distortions that are responsible for urban sprawl: (i) land-use externalities in terms of incorrect pricing (incomplete cost transfer of development costs for housing) in low-density areas and (ii) transport externalities in terms of unaccounted external effects such as on health and pollution. As expected, the direct impact of both instruments appears to be most effective. As reported in Table 11, both spatial planning instruments induce a proportion of the population to relocate, reflected by a substantial rise in residential density in urban areas. By contrast, a rise in transport costs lead to a fall in transport volume of motorized private transport as well as a shift in the modal split in favor of public transport (see Table 11). However, in terms of indirect effects, we find that spatial planning instruments do have a significant impact on transport volume (see Table 11) and the number of trips. Reversely, the impact of transport pricing policies on land use is much smaller (e.g., residential density in urban areas increases by 1 percent).

For this comparison to be meaningful, how do the stringency levels compare of spatial policy on the one hand and transport policy on the other? As reported in Table 11, we have defined the stringency level of spatial policies to reduce outward commuters originating in DR and SR by 10 percent. As a direct effect, this increases urban density by 10 to 12 percent (which we might label an indicator of urban sprawl). The direct effect on private motorized transport of the respective transport policy stringency level (variable transport costs rise by a factor of 1.3) that we consider to be at the upper end of currently politically feasible is only half of the former level (i.e., a 6 percent reduction). For the indirect effect, we find a somewhat stronger difference. While spatial policy does reduce private motorized transport by 2 to 3 percent, the particular transport policy stringency level reduces urban sprawl (measured as increase in urban density) by 1 percent. Moreover, only a rise in variable transport costs by a factor of five would double the latter impact (reduce urban sprawl by 2 percent). Simultaneously, we see the case for a proper combination of the two policy approaches. When adding a public transport policy element to the spatial policy, private motorized transport can be reduced by 12 percent.
Table 11: Overall changes in transport volume for MPT and PT and residential density in urban areas by policy scenario relative to $\mathrm{BaU} 2025$

\begin{tabular}{|c|c|c|c|c|}
\hline $\begin{array}{l}\text { Implemented } \\
\text { at stringency } \\
\text { level of }\end{array}$ & $\begin{array}{l}\text { Policy Sce- } \\
\text { nario }\end{array}$ & $\begin{array}{l}\mathbf{M P T}^{\mathbf{b}} \\
{[\mathrm{p}-} \\
\left.\mathrm{km}^{\mathrm{a}}\right]\end{array}$ & $\begin{array}{l}\mathbf{P T}^{\mathbf{c}} \\
{[\mathrm{p}-} \\
\left.\mathrm{km}^{\mathrm{a}}\right]\end{array}$ & $\begin{array}{l}\text { Residential } \\
\text { density in } \\
\text { urban areas } \\
{[\text { persons per }} \\
\left.\mathrm{km}^{2}\right]\end{array}$ \\
\hline \multicolumn{2}{|c|}{ BaU2025 (absolute values) } & 20,802 & 3309 & 1609 \\
\hline $\begin{array}{l}10 \% \text { reduction } \\
\text { of outward } \\
\text { commuters } \\
\text { originating in } \\
\text { DR and SR }\end{array}$ & $\begin{array}{l}\text { Area limita- } \\
\text { tion } \\
\text { Expansion of } \\
\text { building land }\end{array}$ & $-3 \%$ & $-4 \%$ & $+10 \%$ \\
\hline $\begin{array}{l}10 \% \text { reduction } \\
\text { of outward } \\
\text { commuters } \\
\text { originating in } \\
\text { DR and SR } \\
\text { plus improved } \\
\text { public } \\
\text { transport }\end{array}$ & $\begin{array}{l}\text { Area limita- } \\
\text { tion \& public } \\
\text { transport } \\
\text { Expansion of } \\
\text { building land } \\
\& \text { public } \\
\text { transport }\end{array}$ & $-12 \%$ & $+12 \%$ & $+12 \%$ \\
\hline
\end{tabular}

\begin{tabular}{|c|c|c|c|c|}
\hline $\begin{array}{l}\text { Increase in } \\
\text { variable } \\
\text { transport costs } \\
\text { by } 30 \%\end{array}$ & $\begin{array}{l}\text { Transport } \\
\text { pricing policy }\end{array}$ & $-6 \%$ & $+2 \%$ & $+1 \%$ \\
\hline
\end{tabular}

The result that spatial planning instruments work strongly on households' settlement decisionwhereas transport pricing measures have a minor impact on residential choice and hence little influence on urban sprawl - is worthy of further discussion. Our results suggest that transport costs play a minor role for households' location decision, while housing prices represent a core driving force for spatial relocation of households. Empirical studies that are available in the literature to date are ambiguous with respect to this result, however. Concerning rural regions, Marler (2006) and May et al. (2003) find - in line with our results - that spatial planning instruments are more efficient to curb sprawl and that transport pricing instruments are less efficient. In contrast, but with respect to urban regions, Kim et al. (2005) claim that travel costs (e.g., fuel costs) are of key importance for residential choice. We find that by covering both urban and rural regions in our analysis, it is the substantial difference in housing prices and its reaction to spatial policy that govern residential choice decisions. Note 
that initial housing prices in urban regions are three to ten times the level found in rural regions. Thus, bringing our results in alignment with $\mathrm{Kim}$ et al. (2005), when the focus is on a regional setting characterized by substantial price differentials in land prices (as is the case in our approach), it is land prices that govern location decisions (rather than transport prices). If the focus is on a narrower (e.g., urban) setting (as in Kim et al. 2005), with less land price divergence (prices in central regions still being two to three times those of peripheral ones), transport cost considerations may gain in relative importance in location choices.

Our results also underline that the time scale of both policies is of key relevance. There is a broad array of empirical literature confirming that future costs are discounted in relation to current costs depending on time frames and uncertainties in estimating future costs (for an overview see Frederick et al. 2002). Differences in the impact time scale of both polices (transport demand response vs. land-use changes) indicate that households do not (or do not strongly) consider the long-term impact on transport costs that is implied by location choice. In terms of discounting, this implies high discount rates for future transport costs. Resettlement or the purchase of a house (or other home) involves high investment costs. Land or property development costs that arise upfront and directly are more important in location choice than the sum of transport costs now and in the future.

A sensitivity analysis reveals that our findings are most dependent on parameter assumptions regarding the elasticity of substitution $\sigma$ between housing $\mathrm{H}$ and the manufacturing good $\mathrm{M}$ as well as the elasticity of substitution $\varepsilon$ between domestic $\mathrm{H}$ and $\mathrm{H}$ abroad. When testing for sensitivity of results by doubling these parameter values and setting them at half of their values, we find that the magnitude of the effect of transport policy on residential population depends on the choice of elasticity of substitution values. The impact in all cases, however, remains of quite low relevance (decreases in all combinations remain below 1.1 percent and increases below 0.9 percent; sensitivity results are given in detail in Table A-2 in the Appendix). Thus, our result of transport policy hardly influencing residential choice is quite robust with respect to behavioral parameter values in a coupled modeling approach covering urban and rural areas.

\section{Conclusions}

This paper studies the interlinkage of spatial planning and transport spheres and its relevance in terms of policy options to curb European urban sprawl and transport implications thereof. The focus is on spatial planning instruments and transport pricing policy. We study the direct link of spatial planning instruments on land use and housing prices as well as their indirect effect on transport demand. Regarding transport pricing policy, we also analyze the direct impact of an increase in variable transport cost on transport demand as well as the potential to influence residential choice as indirect link. The clear focus is to go beyond the analysis of direct links and to study the indirect impacts of both policy options.

To address these issues, we link a multi-region computable general equilibrium model (CGE model), which depicts households' interdependent location choice of residence and place of work, with the Austrian traffic forecast model reporting overall transport volume, number of trips, and modal split. In doing so, our modeling device complements existing approaches at two ends. First, it considers endogenous residential choice using the New Economic Geography-based CGE model, and second, it includes a detailed depiction of the transport sector delivered only by traffic forecast models.

Our results suggest that while transport policy is naturally effective in addressing transport externalities, it would have to be set at a politically infeasible stringency to have an effect on residential patterns. This result seems to contradict findings of some of the existing literature while supporting others. We can separate our results by identifying the geographical scale of analysis as the decisive parameter to govern the relevance of transport cost changes over land price (divergences). More specifically, when a study restricts itself to a comparatively homogenous land market (i.e., focusing on an urban area only, or on rural only), transport price changes can easily dominate the, in this case low, land price divergences in the study region, and thus will have a significant influence on residential location. If, however, as is the case in our study, the study area comprises both urban and rural locations and is thus characterized by a large divergence in land prices, then transport price changes would have to be enormous to dominate land price divergences. Thus, we can explain an important element of study design governing the relevance of transport price changes for 
residential location decisions. When analyzing urban sprawl, which is governed by significant interregional land price divergences, as we do here, a change in transport costs does not have a major impact on limiting urban sprawl.

As for the second policy analyzed, we find that spatial planning causes the number of trips and transport volume to fall, but it hardly affects modal split. From that we conclude that compact and dense settlement structures are a necessary but not sufficient condition to change the car being the prime mode of transport. Thus, the paradigm that dense and compact residential development with mixeduse neighborhoods alone would promote environmentally friendly modes of transport does not hold. Additional efforts are necessary.

Along that line, and as a complementary result, we find that improved access to public transport as a supplement to spatial planning-hence addressing both externalities - is most efficient in terms of land use and transport effects. On the one hand, spatial planning instruments promote the attractiveness of urban areas, triggering relatively lower land prices and thus inducing a proportion of the population to resettle. On the other hand, improved access to public transport favors environmentally friendly modes of transport such as public transport and bike. These findings suggest that, complementary to spatial policy, further incentives in transport policy are of key importance - such as expansion or quality improvement of public transport supply or transport demand management instrument - to change modal choice.

The methodological approach used in this study has some limitations that should be addressed in future work. The first one concerns the level of resolution in RCM: An improvement would be to consider location choice also within a region. Second, other factors influencing residential choice such as neighborhood amenities (e.g., a viable landscape or air quality), which were not considered here for matters of aggregated data analysis (and thus also to avoid higher complexity of the model structure), could be included in future modeling exercises.

\section{$8 \quad$ Acknowledgments}

For inspiring discussions and comments on earlier versions of this paper we thank Birgit BednarFriedl, Tom Rutherford, Kay Axhausen, and anon- ymous reviewers of this journal. We also thank the Austrian Climate and Energy Fund for financial support of this research (project ORD.EFF).

\section{References}

Abraham, J. E. and J. D. Hunt. 1999. Policy analysis using the Sacramento MEPLAN land usetransportation interaction model. Transportation Research Record 1685: 199-208. http://dx.doi.org/10.3141/1685-25.

Anas, A. and I. Kim. 1996. General equilibrium models of polycentric urban land use with endogenous congestion and job agglomeration. Journal of Urban Economics 40(2): 232-256. http://dx.doi.org/10.1006/juec.1996.0031.

Anas, A. 1998. NYMTC Transportation Models and Data Initiative: The NYMTC Land Use Model. Williamsville, New York: Alex Anas \& Associates.

Anas, A. and Y. Liu. A regional economy, land use, and transportation model (Relu-Tran $\odot$ ): Formulation, algorithm design, and testing. Journal of Regional Science 47(3): 415-455. http://dx.doi.org/10.1111/j.1467-

9787.2007.00515.x.

Bednar-Friedl, B., O. Koland, and K. Steininger. 2011. Urban sprawl and policy responses: A general equilibrium analysis of residential choice. Journal of Environmental Planning and Management 54(1): 145-168. http://dx.doi.org/10.1080/09640568.2010.502766.

Belart, B. 2011. Wohnstandortwahl im Großraum Zürich. Master's thesis, ETH Zurich.

Bento, A. M., M. L. Cropper, A. M. Mobarak, and K. Vinha. 2005. The effects of urban spatial structure on travel demand in the United States. Review of Economics and Statistics 87(3): 466-478. http://dx.doi.org/10.1162/0034653054638292.

Bento, A. M., S. F. Franco, and D. T. Kaffine. 2006. The efficiency and distributional impacts of alternative anti-sprawl policies. Journal of Urban Economics 59(1): 121-141. http://dx.doi.org/10.1016/j.jue.2005.09.004.

- 2009. Efficiency and spatial impacts of development taxes: The critical role of alternative revenue-recycling schemes. American Journal of Agricultural Economics 91(5): 1304-1311. http://dx.doi.org/10.1111/j.1467-

8276.2009.01302.x. 
Bontje, M. 2007. Deconcentration and commuter traffic: trends and policies in the Netherlands. Informationen zur Raumentwicklung 2/3.

Boyce, D. and H. Bar-Gera. 2003. Validation of multiclass urban travel forecasting models combining origin-destination, mode, and route choices. Journal of Regional Science, 43(3): 517-540. http://dx.doi.org/10.1111/1467-9787.00309.

Brueckner, J. 2000. Urban sprawl: Diagnosis and remedies. International Regional Science Review, 23(2): 160-171. http://dx.doi.org/10.1177/016001700761012710.

Burchfield, M., H. G. Overman, D. Puga, and M. A. Turner. 2006. Causes of sprawl: A portrait from space. Quarterly Journal of Economics 121(2). http://dx.doi.org/10.1162/qjec.2006.121.2.587.

Echenique, M. H., D. Crowther, and W. Lindsay. 1969. A spatial model for urban stock and activity. Regional Studies 3(3): 281-312. http://dx.doi.org/10.1080/09595236900185291

DHAC (Department of Health and Aged Care). 2001. Measuring remoteness: Accessibility/Remoteness Index of Australia (ARIA). Working Paper No. 14.

Dixit, A. K. and J. E. Stiglitz. 1977. Monopolistic competition and optimum product diversity. American Economic Review, 67(3): 297-308.

EEA (European Environment Agency). 2006. Urban Sprawl in Europe: The Ignored Challenge. EEA Report No 10/2006.

Eppink, F. K. and C. A. Withagen. 2009. Spatial patterns of biodiversity conservation in a multiregional general equilibrium model. Resource and Energy Economics 31(2): 75-88. http://dx.doi.org/10.1016/j.reseneeco.2008.09.007.

EU. 2008. Rural development in the European Union: Statistical and economic information. Directorate-General for Agriculture and Rural Development.

Ewing, R., R. Pendall, and D. Chen. 2003. Measuring sprawl and its transportation impacts. Transportation Research Record 18(31): 175-183. http://dx.doi.org/10.3141/1831-20.

Fujita, M., P. Krugman, and A. J. Venables. 1999. The Spatial Economy: Cities, Regions, and International Trade. Cambridge, Massachusetts: MIT Press.

Frederick, S., G. Loewenstein, and T. O'Donoghue. 2002. Time discounting and time preference: A critical review. Journal of Economic Literature 40(2): 351-401.
Friedwagner, A. and T. Langthaler. 2007. KORS - Verkehrsreduktion durch kompakte Raumstrukturen. Real Corp 2007 Proceedings, Vienna.

Gallez C. and J. P. Orfeuil. 1998. Dis moi où tu habites, je te dirai comment tu te déplaces. In Pumain D. and M. F. Mattei Données urbaines 2. Anthropos: 157-164.

Glaeser, E. and M. E. Kahn. 2004. Sprawl and urban growth. In Handbook of Regional and Urban Economics 4, edited by J. V. Henderson and J. F. Thisse, 2480-2526. Amsterdam: Elsevier Science \& Technology Books.

Grazi, F., J. C. J. M. van den Bergh, and J. N. van Ommeren. 2008. An empirical analysis of urban form, transport, and global warming. The Energy Journal 29(4): 97-122. http://dx.doi.org/10.5547/ISSN0195-6574-EJVol29-No4-5.

Henry M. S., D. L. Barkley D. L., and S. Bao. 1997. The hinterland's stake in metropolitan growth: Evidence from selected southern regions. Journal of Regional Science 37(3): 479-501. http://dx.doi.org/10.1111/0022-4146.00065.

Hunt, J. D. and D. C. Simmonds 1993. Theory and application of an integrated land-use and transport modeling framework. Environment and Planning B: Planning and Design 20(2): 221-44. http://dx.doi.org/10.1068/b200221

Käfer, A., K. Steininger, K. Axhausen, E. Burian, L. Clees, O. Fritz, B. Fürst, B. Gebetsroither, C. Grubits, P. Huber, R. Kurzmann, R. Molitor, G. Ortis, G. Palme, H. Peherstorfer, D. Pfeiler, S. Schönfelder, K. Siller, G. Streicher, O. Thaller, S. Wiederin, G. Zakarias. 2009. Verkehrsprognose 2025+ ENDBERICHT, im Auftrag des BMVIT, Vienna.

Kenworthy, J. R. and F. B. Laube. 1999. Patterns of automobile dependence in cities: An international overview of key physical and economic dimensions with some implications for urban policy. Transportation Research Part A 33: 691-723.

Kilkenny, M. 1998. Transport costs and rural development. Journal of Regional Science 38(2): 293 312. http://dx.doi.org/10.1111/1467-9787.00093.

Kim, J., H. Pagliara, and F. Preston. 2005. The intention to move and residential location choice behaviour. Urban Studies 42(9): 1621-1631. http://dx.doi.org/10.1080/00420980500185611

Kim, Y., D. L. Barkley, and M. S. Henry. 2000. Industry characteristics linked to establishment concentrations in nonmetropolitan areas. Journal of Re- 
gional Science 40(2): 231-259. http://dx.doi.org/10.1111/0022-4146.00173.

Krugman, P. 1991a. Increasing returns and economic geography. Journal of Political Economy 99(3): 483-499. http://dx.doi.org/10.1086/261763.

—. 1991b. Geography and Trade. Cambridge, Massachusetts: MIT Press.

Kutter, E. 2003. Modellierung für die Verkehrsplanung - Theoretische, empirische und planungspraktische Rahmenbedingungen, ECTL Working Paper 21, Technical University HamburgHarburg.

Lohse, D. 1997. Ermittlung von Verkehrsströmen mit n-linearen Gleichungssystemen unter Beachtung von Nebenbedingungen einschließlich Parameterschätzung (Verkehrsnachfragemodellierung: Erzeugung, Verteilung, Aufteilung). Schriftenreihe des Instituts für Verkehrsplanung und Straßenverkehr 5.

Marler, N. 2006. Land use: development densities \& mix. EU project DISTILATE (Design and Implementation Support Tools for Integrated Local Land Use, Transport and the Environment) Appen$\operatorname{dix} \mathrm{C}$.

Martinez, F. J. 1992. The bid-choice land-use model: an integrated economic framework Environment and Planning A 24(6): 871-85. http://dx.doi.org/10.1068/a240871.

Martinez, F. J. 1997. MUSSA: A Land Use Model for Santiago City. Santiago, Chile: Department of Civil Engineering, University of Chile.

May, A., A. Karlstrom, N. Marler, B. Matthews, H. Minken, A. Monzon, M. Page, P. Pfaffenbichler, and S. Shepherd. 2003. Decision Makers Guidebook. EU-project PROSPECTS.

Mayers, I., S. Ochelsen, and S. Proost. 1996. The marginal external costs of urban transport. Transportation Research Part D: Transport and Environment 1(2): 111-130. http://dx.doi.org/10.1016/S13619209(96)00006-5.

Najafi, M., M. Rayman, A. K. Tayebi, S. Adelaja, and M. B. Lake. 2007. Fiscal impacts of alternative single-family housing densities. Journal of Urban Planning and Development, 133(3): 179-187. http://dx.doi.org/10.1061/(ASCE)0733-

9488(2007)133:3(179).

OECD. 2010. OECD Regional Typology. Directorate for Public Governance and Territorial Development.

Proost, S. and K. van Dender. 2011. What longterm road transport future? Trends and policy op- tions. Review of Environmental Economics and Policy 5(1): 44-65. http://dx.doi.org/10.1093/reep/req022.

Radeloff, V. C., R. B. Hammer, and S. I. Stewart. 2005. Rural and suburban sprawl in the U.S. Midwest from 1940 to 2000 and its relation to forest fragmentation. Conservation Biology 19(3): 793$805 . \quad$ http://dx.doi.org/10.1111/j.15231739.2005.00387.x.

Schmitt B., V. Piguet, M. Hilal, and M.S. Henry. 2006. Urban growth effects on rural population, export and service employment: Evidence from eastern France. Annals of Regional Science 40(4). http://dx.doi.org/10.1007/s00168-006-0069-3.

Speir, C. and K. Stephenson. 2002. Does sprawl cost us all? Isolating the Effects of Housing Patterns on Public Water and Sewer Costs. Journal of the American Planning Association 68(1): 56-710. http://dx.doi.org/10.1080/01944360208977191.

Statistics Austria. 2003. Population census 2001. Vienna.

- 2004. Commuter matrix 2001. Vienna.

- 2005. Selected indicators at municipal level 2001. Vienna.

. 2006. Austrian Household Consumption Survey 2004/05. Vienna.

Trowbridge, M. J. and N. C. McDonald. 2008. Urban sprawl and miles driven daily by teenagers in the United States. American Journal of Preventive Medicine 34(3): 202-206. http://dx.doi.org/10.1016/j.amepre.2007.11.013.

Travisi, C. M., R. Camagni, and P. Nijkamp. 2010. Impacts of urban sprawl and commuting: a modeling study for Italy. Journal of Transport Geography 18(3): 382-392. http://dx.doi.org/10.1016/j.jtrangeo.2009.08.008.

Vance, C. and R. Hedel. 2007. The impact of urban form on automobile travel: disentangling causation from correlation. Transportation 34(5): 575588. http://dx.doi.org/10.1007/s11116-007-9128-6.

Verhoef, E. 1994. External effects and social costs of road transport. Transportation Research Part A: Policy and Practice, 28(4): 273-287.

Wegener, M. 2004. Overview of land-use transport models. In Transport Geography and Spatial Systems. Handbook 5 of the Handbook in Transport, edited by D.A. Hensher and K. Button, 127-146. Kidlington, UK: Pergamon/Elsevier Science.

Waddell, P. 2000. A behavioral simulation model for metropolitan policy analysis and planning: 
residential location and housing market components of UrbanSim. Environment and Planning B 27: 247263. http://dx.doi.org/10.1068/b2627.

. 2002. UrbanSim: Modeling urban development for land use, transportation, and environmental planning. Journal of the American Planning Association 68(3): 297-343. http://dx.doi.org/10.1080/01944360208976274.

Wegener, M. 2005. Integrated land-use transport modeling. Presented at the Fourth Oregon Symposium on Integrated Land-use Transport Models, November 2005, Portland, Oregon. 


\section{Appendix 1}

Table A-1: Definition of area types

\begin{tabular}{|c|c|c|}
\hline Type of area & Definition & Source \\
\hline Central urban & $\begin{array}{l}\text { More than } 150 \text { inhabitants per } \mathrm{km}^{2} \text {, total popula- } \\
\text { tion of more than } 200,000\end{array}$ & OECD (2010) \\
\hline Peri-urban & $\begin{array}{l}\text { More than } 150 \text { inhabitants per } \mathrm{km}^{2} \text {, population } \\
\text { between } 7000 \text { and } 20,000 \text {, low agricultural activity } \\
\text { (share of labor force in the agricultural sector } \\
\text { lower than } 9.9 \% \text { ) }\end{array}$ & OECD (2010) \\
\hline Densely populated rural & $\begin{array}{l}\text { Less than } 150 \text { inhabitants per } \mathrm{km}^{2} \text {, distance to the } \\
\text { next urban/peri-urban area less than } 20 \mathrm{~km} \text {, share } \\
\text { of outward commuting less than } 75 \% \text {, ratio of } \\
\text { travel time by car to public transport lower than } \\
2.5\end{array}$ & $\begin{array}{l}\text { OECD (2010) } \\
\text { DHAC (2001) }\end{array}$ \\
\hline Sprawled rural & $\begin{array}{l}\text { All other municipalities with less than } 150 \text { inhab- } \\
\text { itants per } \mathrm{km}^{2}\end{array}$ & OECD (2010) \\
\hline
\end{tabular}




\section{Model interface: An illustrative example}

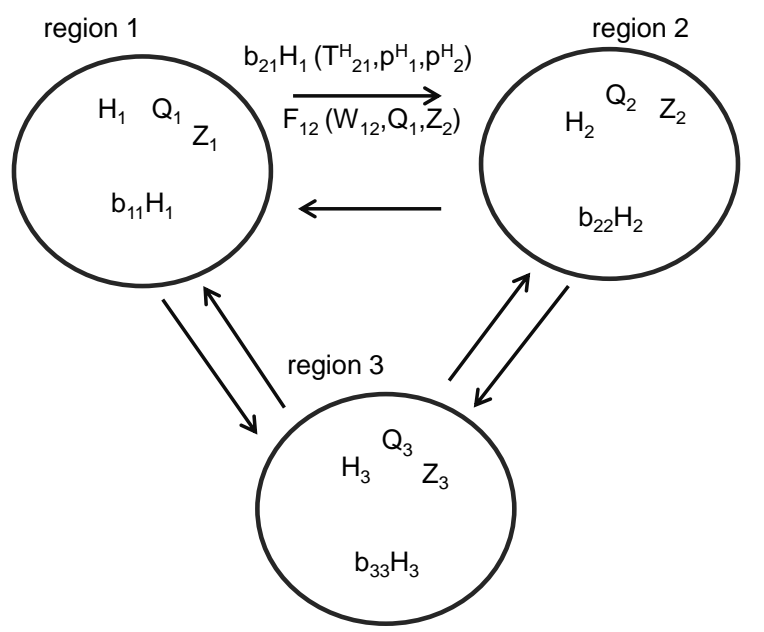

Variables in RCM

$\mathrm{H}_{1} \ldots$ Housing demand region 1

$b_{21} \ldots$ Share of housing exports from region 1 (place of

residence) to 2 (region of job location)

$\mathrm{TH}_{21} \ldots$ Transport costs between region 2 and 1

$\mathrm{pH}_{1}{ }_{1} \ldots$ Housing price region 1

Variables in TFM

$\mathrm{Q}_{1} \ldots$ Trips originating in region 1

$\mathrm{F}_{12} \ldots$ Trip between region 1 and 2

$\mathrm{W}_{12} \ldots$ Resistance between region 1 and 2

$\mathrm{Z}_{2} \ldots$ Number of attractions in region 2

Figure A-1: Model interface between RCM and TFM in a simplified three-zone system.

This illustrative three-zone example shows how parameters and variables of one model are used in the other model. In RCM, $T_{21}$ represents iceberg transport costs between region of place of residence, 1 , and region of job location, 2. As laid out in section 4.1, for parameterization of the iceberg cost "melting factor," we use transport resistance between region 1and region $2, W_{12}$, as measured in TFM, with higher resistance $W$ increasing the melting factor (i.e., transport costs in RCM).

Furthermore, the absolute size of (and policy-induced rates of change in) both the population within each region and the population commuting between all pairs of regions are depicted consistent in both models, RCM and TFM. For instance, the share of housing exports from region 1 to region 2 ( $b_{2 l}$, commuters with job location in region 2 and place of residence in region 1) correlates with commuter trips between region 1 and region 2 . This also requires that housing demand in region $1, H_{1}$, comprising the three subsets, each of which has residence in region 1 , and either working location in region $1\left(b_{11} H_{1}\right)$, region $2\left(b_{21} H_{1}\right)$ or region $3\left(b_{31} H_{1}\right)$ respectively, in $\mathrm{RCM}$ correlates with the respective trips originating in region $1\left(Q_{1}\right)$ and directed at the respective region 1,2 , or 3 . In terms of policy simulation, as indicated in section 2.3, changes in residential population and hence commuting flows resulting in RCM are input in TFM, implying:

$\dot{H}_{1}=\dot{Q}_{1}$

Changes in residential population in region 1 imply changes at an equal rate in trips originating from region 1. Thus, changes in number of commuters living in region 1 and working in region 2 imply changes at an equal rate in number of trips (of work force) from region 1 to region 2:

$\left(\mathrm{b}_{21} \cdot \mathrm{H}_{1}\right)=F_{12}^{\cdot}$

\section{Residential choice model}

Regional housing, $\overline{H_{r}}$ (fixed in supply,) is either demanded by households with job and residence in location $\mathrm{r}, H_{r r}$, or by households with job in location s, $\sum_{s=1}^{R} H_{s r \mid s \neq r}$, (commuters from residence $r$ to job location $s$ ). 


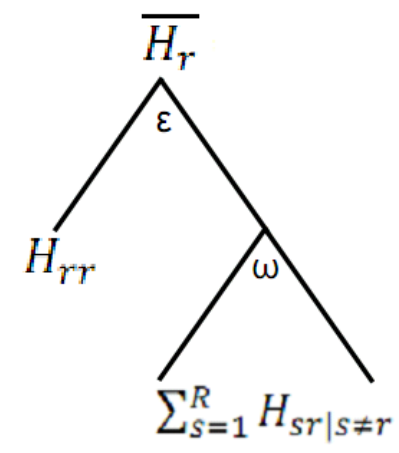

Figure A-2: Nesting of housing $H$ in region $r$

\section{Mode choice in the transport forecast model}

The utility function for motorized individual transport is as follows:

$$
V_{i j}(m, g, z)=p 1(m, g, z) T_{i j}(m)+p 2(m, g, z) Z_{i j}(m)+p 3(m, g, z) C_{i j}(m, g, z)+p 4(m, g, z),
$$

where $p 1(m, g, z)$ to $p 4(m, g, z)$ describe preference (in terms of marginal utility) for mode $m$ of group $g$ on trip purpose $z$.

$$
\begin{array}{ll}
T_{i j}(m) & \text { travel time from } i \text { to } j, \\
Z_{i j}(m) & \text { access/departure time from } i \text { to } j, \\
C_{i j}(m, g, z) & \text { cost from } i \text { to } j \text { and } \\
p 4(m, g, z) & \text { additional utility constant }
\end{array}
$$

The utility function for public transport is as follows:

$$
\begin{aligned}
& V_{i j}(m, g, z) \\
& =p 1(m, g, z) T_{i j}(m)+p 2(m, g, z) Z_{i j}(m)+p 3(m, g, z) C_{i j}(m, g, z)+p 4(m, g, z) \\
& ++p 5(m, g, z) f\left(U M H_{i j}(m, g, z), D_{i j}\right)+p 6(m, g, z) f\left(T K T_{i j}(m)\right)+p 7(m, g, z) U G Z_{i j}(m) \\
& +p 8(m, g, z) U W Z_{i j}(m)
\end{aligned}
$$

where $p 1(m, g, z)$ to $p 8(m, g, z)$ describe preference (in terms of marginal utility) of group $g$ for mode $m$ on trip purpose $z$.

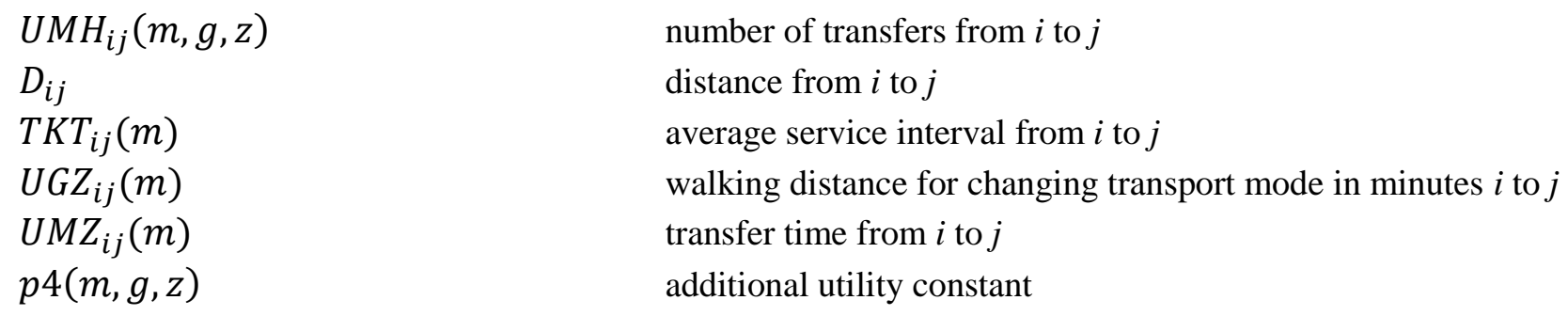




\section{Calibration of RCM}

Table A-2: Distribution of residential population and workforce and bias to real data (2001) for the four representative regions

\begin{tabular}{lllllr}
\hline \multirow{3}{*}{ Residents } & & UA & PUA & DRA & SRA \\
& Model & $27.16 \%$ & $19.91 \%$ & $23.95 \%$ & $28.99 \%$ \\
& Real data & $26.87 \%$ & $17.19 \%$ & $20.47 \%$ & $35.48 \%$ \\
& Bias & $+0.29 \%$ & $+2.72 \%$ & $+3.48 \%$ & $-6.49 \%$ \\
\hline \multirow{3}{*}{ Workforce } & Model & $40.21 \%$ & $24.64 \%$ & $16.06 \%$ & $19.09 \%$ \\
& Real data & $41.47 \%$ & $26.47 \%$ & $15.42 \%$ & $16.64 \%$ \\
& Bias & $-1.26 \%$ & $-1.83 \%$ & $+0.64 \%$ & $+2.45 \%$ \\
\hline
\end{tabular}

Source: Statistics Austria (2003, 2004, 2005)

\section{Sensitivity analysis}

Table A-3: Changes in residential population of transport pricing policy for different values of $\varepsilon$ and $\sigma$

\begin{tabular}{llllll}
\hline $\boldsymbol{\sigma}$ & $\boldsymbol{\varepsilon}$ & $\mathbf{C U}$ & $\mathbf{P U}$ & $\mathbf{D R}$ & $\mathbf{S R}$ \\
\hline $\mathbf{1}$ & $\mathbf{1}$ & $+0.22 \%$ & $+0.19 \%$ & $+0.56 \%$ & $-0.80 \%$ \\
\hline $\mathbf{2}$ & $\mathbf{1}$ & $+0.01 \%$ & $+0.54 \%$ & $+0.85 \%$ & $-1.10 \%$ \\
$\mathbf{0 . 5}$ & $\mathbf{1}$ & $+0.40 \%$ & $+0.49 \%$ & $+0.40 \%$ & $-0.67 \%$ \\
$\mathbf{1}$ & $\mathbf{2}$ & $+0.01 \%$ & $+0.51 \%$ & $+0.40 \%$ & $-0.65 \%$ \\
$\mathbf{1}$ & $\mathbf{0 . 5}$ & $+0.33 \%$ & $+0.01 \%$ & $+0.88 \%$ & $-0.74 \%$ \\
$\mathbf{2}$ & $\mathbf{0 . 5}$ & $+0.01 \%$ & $+0.01 \%$ & $+0.89 \%$ & $-0.77 \%$ \\
$\mathbf{0 . 5}$ & $\mathbf{2}$ & $+0.43 \%$ & $+0.51 \%$ & $+0.39 \%$ & $-0.63 \%$ \\
$\mathbf{2}$ & $\mathbf{2}$ & $+0.38 \%$ & $+0.01 \%$ & $+0.40 \%$ & $-0.69 \%$ \\
$\mathbf{0 . 5}$ & $\mathbf{0 . 5}$ & $+0.36 \%$ & $+0.01 \%$ & $+0.84 \%$ & $-0.37 \%$ \\
\hline
\end{tabular}

